\title{
Immunocontraception of mammalian wildlife: ecological and immunogenetic issues
}

\author{
Desmond W Cooper and Elisabeth Larsen \\ Australian and New Zealand Conservation Laboratories, School of Biological, Earth and Environmental Sciences, \\ The University of New South Wales, Sydney, New South Wales 2052, Australia
}

Correspondence should be addressed to DW Cooper; Email: des.cooper@unsw.edu.au

\begin{abstract}
Immunocontraception involves stimulating immune responses against gametes or reproductive hormones thus preventing conception. The method is being developed for the humane control of pest and overabundant populations of mammalian wildlife. This paper examines three fundamental issues associated with its use: (1) the difficulties of obtaining responses to self-antigens, (2) the likely evolution of genetically based non-response to immunocontraceptive agents, and (3) the possible changes in the array of pathogens possessed by the target species after generations of immunocontraception. Our review of the literature demonstrates that the barriers to an effective immunocontraceptive are at present very basic. Should they be overcome, the effects of immunocontraception on the immunogenetic constitution of wildlife populations through the selection for nonresponders must be examined. We suggest that the attempt to use the animal's own immune system to modulate reproduction may be incompatible with the basic biological function of protection against infectious disease. Research programs on mammalian immunocontraception should involve measurement of the heritability of non-response and an assessment of the likely change in the response of the contracepted population to possible pathogens.

Reproduction (2006) $132821-828$
\end{abstract}

\section{Introduction}

The regulation of human and animal population numbers constitutes a difficult and largely unsolved contemporary problem. In the developed world, steroid contraceptives for humans are both widely used and efficacious. Elsewhere they are too costly. The development of less expensive methods is considered necessary (Aitken et al. 1993). One such method is immunocontraception, i.e. the vaccination against sperm, eggs, or reproductive hormones to prevent either fertilization or the production of gametes. Attempts to design human immunocontraception have a long history (Joshi 1973, Stevens 1975, Basten 1988, Gupta \& Talwar 1994). The targets include sperm antigens, oocyte antigens, especially zona pellucida proteins (PZP), gonadotropin riboflavin carrier protein, gonadotropins and gonadotropin releasing hormones (Delves et al. 2002). The most advanced method involves immunization against human chorionic gonadotropin, in reality a method of very early pregnancy termination (Baird 2000). It now seems likely that problems associated with autoimmune disease and variability of response will prevent any widespread use of immunocontraception in humans in the foreseeable future (Rao 2001, Aitken 2002). Women's health advocates have objected to all forms of immunocontraception because of perceived health risks and the potential for political abuse of the vaccine (Richter 1994). Human male immunocontraceptives have received much less attention and do not appear to be feasible in the near future (Delves et al. 2002).

Immunocontraceptives for wild animals have a different objective than those for humans. Their main aim is to check population growth rather than to contracept particular individuals. If some animals are irreversibly sterilized so much the better whereas such an effect in human medicine would be ethically most undesirable. Immunocontraceptives for animals are ostensibly humane and could potentially be used on the large scale required for wildlife population regulation. Research progress to date has been reviewed in Tyndale-Biscoe $(1991,1994)$, Barber \& Fayrer-Hosken (2000), Barlow (2000), and Cooper \& Herbert (2001). Three fundamental questions remain to be addressed: (1) Can sufficiently strong immune responses be provoked against the antigens (immunogens) of gametes or reproductive hormones to cause contraception in a proportion of animals large enough for effective 
population management? (2) How rapidly will variation in these responses lead to the evolution of failure to respond to the immunocontraceptive agent? (3) What will be the ecological consequences of the likely changes to the immunogenetic constitution of the population as a result of selection for non-responders? In particular, will the endemic pathogens of the species change? There is considerable information which allows us to answer at least in part the first two questions. The third is of fundamental importance but even a preliminary answer is not possible at present.

\section{Target species}

Population control of native and exotic mammals is generally justified by environmental degradation, competition with and predation on native wildlife, conflicts with humans over food production, potential spread of pathogenic infectious diseases and the possibility of population crashes of over-abundant fauna or of wildlife populations near urban areas. Although still in its infancy, immunocontraception is regarded as being more humane than the traditional methods of wildlife population control, such as shooting, trapping, poisoning, or pathogenic agents and its use has strong support from influential animal welfare agencies worldwide (Oogjes 1997, Grandy \& Rutberg 2002). Table 1 lists mammalian species for which immunocontraception is being investigated and for which the method could be applied. In all these species, there are at present no completely efficacious, cost-effective, or socially acceptable methods for population regulation available.

\section{Immune responses to self-antigens}

Responses to self-antigens are unusual and mainly weak. This constitutes a major barrier to the development of an immunocontraceptive. Table 2 summarizes data on attempts to induce immunocontraception using a variety of antigens in 14 mammalian species. The data in Table 2 show that in most cases a significant proportion of the population is not contracepted by administration of the immunocontraceptive antigen. The reason for this could be either genetic or environmental. In either case it indicates that a fraction of the population will continue to breed despite the administration of the contraceptive. In most cases, there is likely to be at least in part genetic causes underlying lack of response. If so, the genes for lack of response will be selected for and in a comparatively small number of generations most of the population will be non-responsive. This implies that the immunocontraceptive can be useful for only a short period of time.

All studies summarized in Table 2 involve the use of some kind of adjuvant, i.e. a substance or array of substances designed to enhance the immune response. There are no reports of successful immunocontraception without some form of adjuvant. Moreover, most immunizations were boosted at least once (see Table 2). The need for multiple injections and the dependence upon adjuvant to achieve the necessary level of response renders the whole approach impractical at present. The most commonly used adjuvant, Freund's Adjuvant, also induces a range of undesirable side effects and its use is being challenged on animal welfare grounds (Leenaars et al. 1994, 1998). There is at present no feasible or acceptable method of promoting responses to selfantigens sufficient to cause immunocontraception.

Jackson et al. (2001) attempted to overcome the problem of lack of immune response to self-antigens in the absence of adjuvant by inserting the cytokine interleukin-4 into mousepox virus with the intention of increasing the humoral response. The virus was then inserted into the mice with the unwelcome outcome that the mice all died very quickly. This work caused alarm because of the possibility that this technology could lead to a method for simple conversion of relatively innocuous viruses into lethal ones, which could be used in biological warfare (Finkel 2001).

Another possible problem with virus-vectored immunocontraception is the potential for the horizontal transfer of the immunocontraceptive gene into viruses affecting other species (Becker 2000). While it may be possible to create genetically modified organisms without adverse effects on the target animals, the effects they might have on related species they come in contact with make any use of this approach questionable.

\section{Variation in response and genetic change}

Variation in response to biocontrol agents is a widespread phenomenon. This variation has frequently led to evolution of a degree of resistance so that the agent is no longer useful. The evolution of resistance to insecticides has been reviewed by McKenzie (1996). He draws a distinction between biocontrol agents with responses within the phenotypic range and those with responses outside the phenotypic range of the target species. An agent which initially kills all members of the target species is acting outside the normal phenotypical range, while one which kills only a fraction of the population is acting within the normal phenotypical range. He points out that when resistance appears in the former case it is frequently monogenic, while in the latter case a number of different genetic regions are involved, i.e. it is probably multifactorial. The basic genetic parameter to be estimated in either case is heritability, i.e. the extent to which genetic variation is controlled by genetic as opposed to environmental factors. The relative fertility of the immunocontracepted animals in Table 2 is $>10 \%$ in 27 out of the 32 data sets. A proportion of non-responders is characteristic of most species. Only three species (Tammar wallaby, Fallow deer and Norway rat) out of 14 had no nonresponders (Table 2). Following McKenzie's (1996) 
Table 1 Immunocontraception: target species and justification for fertility control.

\begin{tabular}{|c|c|c|c|c|}
\hline Species & Location & $\begin{array}{l}\text { Management } \\
\text { issues }\end{array}$ & $\begin{array}{l}\text { Population } \\
\text { control needs }\end{array}$ & References \\
\hline \multicolumn{5}{|l|}{ K-selected species } \\
\hline Koala & $\begin{array}{l}\text { Australia; local } \\
\text { overpopulations }\end{array}$ & $\begin{array}{l}\text { Habitat degradation; likely destruc- } \\
\text { tion of own habitat; highly regarded } \\
\text { species }\end{array}$ & $\begin{array}{l}\text { Control methods with public } \\
\text { acceptance }\end{array}$ & $\begin{array}{l}\text { Martin \& Handasyde } \\
\text { (1999) }\end{array}$ \\
\hline African elephant & Southern Africa & $\begin{array}{l}\text { Habitat degradation; public safety } \\
\text { and health concerns; highly } \\
\text { regarded species }\end{array}$ & $\begin{array}{l}\text { Control methods with public } \\
\text { acceptance }\end{array}$ & Hanks (2001) \\
\hline Wild horse & USA, Australia & $\begin{array}{l}\text { Habitat degradation; conflicts with } \\
\text { livestock, timber and mining indus- } \\
\text { try interests (USA); highly regarded } \\
\text { species }\end{array}$ & $\begin{array}{l}\text { Control methods with public } \\
\text { acceptance }\end{array}$ & $\begin{array}{l}\text { Berger (1986), Dobbie } \\
\text { et al. (1993), Furbish \& } \\
\text { Albano (1994) }\end{array}$ \\
\hline White-tailed deer & USA & $\begin{array}{l}\text { Habitat degradation; public safety } \\
\text { and health concerns; high frequen- } \\
\text { cies of deer-vehicle collisions; crop } \\
\text { and garden damage }\end{array}$ & $\begin{array}{l}\text { Control methods with public } \\
\text { acceptance }\end{array}$ & $\begin{array}{l}\text { McShea et al. (1997), } \\
\text { Warren (1997) }\end{array}$ \\
\hline Feral donkey/Burro & $\begin{array}{l}\text { USA, Australia, } \\
\text { Africa }\end{array}$ & $\begin{array}{l}\text { Habitat degradation; public safety } \\
\text { and health concerns; highly } \\
\text { regarded species }\end{array}$ & $\begin{array}{l}\text { Broad-scale control over large, } \\
\text { remote and inaccessible areas } \\
\text { (Australia) }\end{array}$ & $\begin{array}{l}\text { McCool (1981), Berger } \\
\text { (1986), Freeland \& } \\
\text { Choquenot (1990) }\end{array}$ \\
\hline Brushtail possum & $\begin{array}{l}\text { New Zealand; } \\
\text { major introduced } \\
\text { pest species }\end{array}$ & $\begin{array}{l}\text { Habitat degradation (New Zealand); } \\
\text { public, livestock and wildlife health } \\
\text { concerns; reservoir for bovine } \\
\text { tuberculosis }\end{array}$ & $\begin{array}{l}\text { Broad-scale control over large, often } \\
\text { inaccessible, areas (New Zealand). } \\
\text { Alternative to poison baits (1080) }\end{array}$ & Montague (2000) \\
\hline Macropods & Australia & $\begin{array}{l}\text { Public, livestock and wildlife health } \\
\text { concerns; high frequencies of kan- } \\
\text { garoo-vehicle collisions; highly } \\
\text { regarded species }\end{array}$ & $\begin{array}{l}\text { Control methods with public } \\
\text { acceptance }\end{array}$ & $\begin{array}{l}\text { Dawson (1995), Pople \& } \\
\text { Grigg (1999) }\end{array}$ \\
\hline European red fox & $\begin{array}{l}\text { Australia; major } \\
\text { introduced pest } \\
\text { species }\end{array}$ & $\begin{array}{l}\text { Predation on native wildlife } \\
\text { (Australia); public, livestock and } \\
\text { wildlife health concerns }\end{array}$ & $\begin{array}{l}\text { Control over continental area } \\
\text { (Australia). Alternative to poison } \\
\text { baits (1080) }\end{array}$ & Saunders et al. (1995) \\
\hline Pinnipeds & Worldwide & $\begin{array}{l}\text { Possible contribution to the } \\
\text { depletion of fish stocks }\end{array}$ & $\begin{array}{l}\text { Contraception suggested as humane } \\
\text { alternative to culling }\end{array}$ & $\begin{array}{l}\text { Butterworth et al. } \\
\text { (1988), Brown et al. } \\
\text { (1996), Mohn \& Bowen } \\
\text { (1996) }\end{array}$ \\
\hline Feral cat & $\begin{array}{l}\text { Worldwide; } \\
\text { major introduced } \\
\text { pest species in } \\
\text { Australia }\end{array}$ & $\begin{array}{l}\text { Predation on native wildlife } \\
\text { (Australia); public and wildlife } \\
\text { health concerns }\end{array}$ & $\begin{array}{l}\text { Control over continental area } \\
\text { (Australia) Alternative to poison baits } \\
\text { (1080) }\end{array}$ & $\begin{array}{l}\text { Newsome (1991), } \\
\text { Bomford et al. (1996), } \\
\text { Mahlow \& Slater (1996) }\end{array}$ \\
\hline Feral dog & Worldwide & $\begin{array}{l}\text { Public and livestock safety and } \\
\text { health concerns; predation on native } \\
\text { wildlife (Australia) }\end{array}$ & $\begin{array}{l}\text { Control methods with public } \\
\text { acceptance }\end{array}$ & $\begin{array}{l}\text { Fleming et al. (2001), } \\
\text { Sabeta et al. (2003) }\end{array}$ \\
\hline Feral pig & $\begin{array}{l}\text { Worldwide; } \\
\text { major introduced } \\
\text { pest species in } \\
\text { Australia }\end{array}$ & $\begin{array}{l}\text { Habitat degradation; damage to } \\
\text { economic resources; public, live- } \\
\text { stock and wildlife health concerns }\end{array}$ & $\begin{array}{l}\text { Control methods with public } \\
\text { acceptance }\end{array}$ & Choquenot et al. (1996) \\
\hline Badger & UK & $\begin{array}{l}\text { Public, livestock and wildlife health } \\
\text { concerns; reservoir for bovine } \\
\text { tuberculosis }\end{array}$ & $\begin{array}{l}\text { Control methods with public } \\
\text { acceptance }\end{array}$ & $\begin{array}{l}\text { Krebs et al. (1998), } \\
\text { Donnelly et al. (2003) }\end{array}$ \\
\hline Grey squirrel & $\begin{array}{l}\text { UK; introduced } \\
\text { species }\end{array}$ & $\begin{array}{l}\text { Habitat degradation; threat to the } \\
\text { native Red squirrel }\end{array}$ & $\begin{array}{l}\text { Control methods with public } \\
\text { acceptance }\end{array}$ & Moore et al. (1997) \\
\hline \multicolumn{5}{|l|}{ r-selected species } \\
\hline European rabbit & $\begin{array}{l}\text { Worldwide; } \\
\text { major vertebrate } \\
\text { pest species in } \\
\text { Australia }\end{array}$ & $\begin{array}{l}\text { Habitat degradation; major cost to } \\
\text { agriculture; public, livestock and } \\
\text { wildlife health concerns }\end{array}$ & Broad-scale control over large areas & $\begin{array}{l}\text { Lawson (1995), } \\
\text { Williams et al. (1995) }\end{array}$ \\
\hline Rodents & Worldwide & $\begin{array}{l}\text { Major damage to economic } \\
\text { resources, incl. crops, pastures, } \\
\text { stored grain, livestock, buildings and } \\
\text { infrastructure; public, livestock and } \\
\text { wildlife health concerns }\end{array}$ & $\begin{array}{l}\text { Broad-scale control over large areas. } \\
\text { Species-specific alternatives to } \\
\text { rodenticides }\end{array}$ & $\begin{array}{l}\text { Caughley et al. (1998), } \\
\text { Chambers et al. (1999), } \\
\text { Seamark (2001) }\end{array}$ \\
\hline
\end{tabular}

argument, this implies that non-response is likely to be multi-factorial in genetic terms. There are no data which will allow estimates of the heritability of non-response to immunocontraception in any of the species in Table 2. We are unable to predict the rate at which this characteristic will increase in any one of these populations under the selective influence of immunocontraception. However, some idea of the likely change per generation given the initial frequency of non-responders can be found using Falconer's (1965) model for threshold characters (Table 3). 
Table 2 Relative fertility of immunocontracepted females in 14 mammalian species.

\begin{tabular}{|c|c|c|c|c|c|c|c|}
\hline Species & Immunogen & Adjuvant & $\begin{array}{c}\text { No. of } \\
\text { immunizations }\end{array}$ & $\begin{array}{c}\text { Reproductive } \\
\text { performance } \\
\text { (control, treated) }\end{array}$ & $\begin{array}{c}\text { Statistical } \\
\text { significance }^{\text {a }}\end{array}$ & $\begin{array}{c}\text { Reduction } \\
\text { in relative } \\
\text { fertility }(\%)^{b}\end{array}$ & Reference \\
\hline Baboon & $\begin{array}{l}\mathrm{LDH}_{-}-\mathrm{C}_{4}+ \\
\text { promiscuous } \\
\text { epitope }\end{array}$ & $\begin{array}{l}\text { CGP11637 emulsi- } \\
\text { fied w. Squale- } \\
\text { ne:Arlacel -A }(4: 1)\end{array}$ & 3 & $\begin{array}{l}\text { Offspring/females } \\
10 / 13,4 / 14\end{array}$ & $P<0.02$ & 62 & $\begin{array}{l}\text { O'Hern et al. } \\
(1997)\end{array}$ \\
\hline Brushtail possum & Whole sperm & $\begin{array}{l}\text { Freund's complete } \\
\text { (FCA), Freund's } \\
\text { incomplete (FIA) in } \\
\text { boosters }\end{array}$ & 3 & $\begin{array}{l}\text { Offspring/females } \\
12 / 16,2 / 16\end{array}$ & $P<0.001$ & 83 & $\begin{array}{l}\text { Duckworth } \\
\text { et al. (1998) }\end{array}$ \\
\hline Tammar wallaby & Porcine ZP & FCA, FIA in boosters & 5 & $\begin{array}{l}\text { Offspring/females } \\
4 / 6,0 / 6\end{array}$ & $P<0.05(n=6)$ & 100 & $\begin{array}{l}\text { Kitchener et al. } \\
(2002)\end{array}$ \\
\hline \multicolumn{8}{|l|}{ African elephant } \\
\hline First schedule & Porcine ZP & $\begin{array}{l}\text { Adjuvant used, type } \\
\text { not given }\end{array}$ & 3 & $\begin{array}{l}\text { Offspring/females } \\
16 / 18,8 / 18\end{array}$ & $P=0.005$ & 50 & $\begin{array}{l}\text { Fayrer-Hosken } \\
\text { et al. (2000) }\end{array}$ \\
\hline Second schedule & Porcine ZP & $\begin{array}{l}\text { Adjuvant not } \\
\text { mentioned }\end{array}$ & 2 & $\begin{array}{l}\text { Offspring/females } \\
2 / 10 \text { (no true } \\
\text { control) }\end{array}$ & $P=0.001$ & 77 & $\begin{array}{l}\text { Fayrer-Hosken } \\
\text { et al. (2000) }\end{array}$ \\
\hline Wild horse & Porcine ZP & FCA, FIA in boosters & $3-4$ & $\begin{array}{l}\text { Pregnancy rate } \\
3 / 6,1 / 14\end{array}$ & Not stated & 85 & $\begin{array}{l}\text { Kirkpatrick } \\
\text { et al. (1991) }\end{array}$ \\
\hline \multicolumn{8}{|l|}{ White-tailed deer } \\
\hline First schedule & Porcine ZP & FCA, FIA in booster & 2 & $\begin{array}{l}\text { Fawns/doe years } \\
30 / 16,4 / 16\end{array}$ & $P<0.0001$ & 87 & $\begin{array}{l}\text { Miller et al. } \\
(2000 a)\end{array}$ \\
\hline Second schedule & RC55 & FCA, FIA in booster & 2 & $\begin{array}{l}\text { Fawns/doe years } \\
30 / 16,19 / 14\end{array}$ & $P<0.05$ & 28 & $\begin{array}{l}\text { Miller et al. } \\
(2000 a)\end{array}$ \\
\hline Third schedule & RC75a & FCA, FIA in booster & 2 & $\begin{array}{l}\text { Fawns/doe years } \\
30 / 16,11 / 8\end{array}$ & $P<0.01$ & 27 & $\begin{array}{l}\text { Miller et al. } \\
(2000 a)\end{array}$ \\
\hline Fourth schedule & $\begin{array}{l}\text { Combined } \\
\text { antigens }\end{array}$ & FCA, FIA in booster & 2 & $\begin{array}{l}\text { Fawns/doe years } \\
30 / 16,16 / 8\end{array}$ & $P>0.05$ & 0 & $\begin{array}{l}\text { Miller et al. } \\
(2000 a)\end{array}$ \\
\hline White-tailed deer & $\mathrm{KLH}-\mathrm{GnRH}$ & FCA, FIA in boosters & $2-4$ & $\begin{array}{l}\text { Fawns/doe years } \\
35 / 19,5 / 24\end{array}$ & $P<0.01$ & 89 & $\begin{array}{l}\text { Miller et al. } \\
(2000 b)\end{array}$ \\
\hline White-tailed deer & Porcine ZP & FCA, FIA in boosters & $2-3$ & $\begin{array}{l}\text { Fawns/doe years } \\
35 / 19,25 / 57\end{array}$ & $P<0.01$ & 76 & $\begin{array}{l}\text { Miller et al. } \\
(2000 c)\end{array}$ \\
\hline \multicolumn{8}{|l|}{ White-tailed deer } \\
\hline First schedule & $\mathrm{GnRH}$ & FCA, FIA in boosters & 3 & $\begin{array}{l}\text { Fawns/doe years } \\
110 / 90,36 / 118\end{array}$ & $P<0.0005$ & 75 & $\begin{array}{l}\text { Curtis et al. } \\
\text { (2002) }\end{array}$ \\
\hline Second schedule & Porcine ZP & FCA, FIA in boosters & 3 & $\begin{array}{l}\text { Fawns/doe years } \\
72 / 56,10 / 60\end{array}$ & $P<0.0005$ & 87 & $\begin{array}{l}\text { Curtis et al. } \\
\text { (2002) }\end{array}$ \\
\hline Fallow deer & SpayVac & FCA & 1 & $\begin{array}{l}\text { Pregnancy rate } \\
322 / 334,0 / 22\end{array}$ & $P<0.0001$ & 100 & $\begin{array}{l}\text { Fraker et al. } \\
(2002)\end{array}$ \\
\hline Burro & Porcine ZP & FCA, FIA in boosters & $2-3$ & $\begin{array}{l}\text { Offspring/females } \\
6 / 11,1 / 16\end{array}$ & $P<0.05$ & 88 & $\begin{array}{l}\text { Turner et al. } \\
\text { (1996) }\end{array}$ \\
\hline Grey seal & SIZP (SpayVac) & FCA & 1 & $\begin{array}{l}\text { Pups/female 2.76, } \\
0.22\end{array}$ & $P<0.001$ & 92 & $\begin{array}{l}\text { Brown et al. } \\
(1996,1997)\end{array}$ \\
\hline Tule elk & Porcine ZP & FCA, FIA in boosters & $3-4$ & $\begin{array}{l}\text { Calves/cow years } \\
53 / 91,5 / 104\end{array}$ & Not stated & 91 & $\begin{array}{l}\text { Shideler et al. } \\
(2002)\end{array}$ \\
\hline Cat & Porcine ZP & FCA, FIA in boosters & 5 & $\begin{array}{l}\text { Pregnancy rate } \\
2 / 2,1 / 5\end{array}$ & Not stated & 50 & $\begin{array}{l}\text { Ivanova et al. } \\
\text { (1995) }\end{array}$ \\
\hline \multicolumn{8}{|l|}{ Cat } \\
\hline First schedule & SpayVac & FCA & 1 & $\begin{array}{l}\text { Mean litter size } \\
5.2,4.5\end{array}$ & $P=0.8859$ & 13 & $\begin{array}{l}\text { Gorman et al. } \\
\text { (2002) }\end{array}$ \\
\hline Second schedule & SpayVac & Alum & 1 & $\begin{array}{l}\text { Mean litter size } \\
5.2,4.4\end{array}$ & $P=0.8859$ & 15 & $\begin{array}{l}\text { Gorman et al. } \\
\text { (2002) }\end{array}$ \\
\hline European rabbit & $\begin{array}{l}\text { Myxoma vec- } \\
\text { tored ZPB }\end{array}$ & FCA, FIA in boosters & 3 & $\begin{array}{l}\text { Mean litter size } \\
7.4,7.0\end{array}$ & Not stated & 5 & $\begin{array}{l}\text { Kerr et al. } \\
(1999)\end{array}$ \\
\hline \multicolumn{8}{|l|}{ Norway rat } \\
\hline First schedule & MZPP/KLH & FCA, FIA in boosters & 3 & $\begin{array}{l}\text { Pregnancy rate } \\
7 / 8,4 / 8\end{array}$ & $P>0.05$ & 40 & $\begin{array}{l}\text { Miller et al. } \\
\text { (1997) }\end{array}$ \\
\hline Second schedule & $\mathrm{GnRH} / \mathrm{KLH}$ & FCA, FIA in boosters & 3 & $\begin{array}{l}\text { Pregnancy rate } \\
7 / 8,0 / 8\end{array}$ & $P<0.004$ & 100 & $\begin{array}{l}\text { Miller et al. } \\
\text { (1997) }\end{array}$ \\
\hline Wild mouse & KLH-mZP3 & FCA, FIA in boosters & 5 & $\begin{array}{l}\text { Pregnancy rate } \\
8 / 15,7 / 30\end{array}$ & $P=0.046$ & 56 & $\begin{array}{l}\text { Hardy et al. } \\
(2002 b)\end{array}$ \\
\hline \multicolumn{8}{|l|}{ BALB/c mouse } \\
\hline $\begin{array}{l}\text { First schedule } \\
\text { (71-81 days) }\end{array}$ & Murine rFA-1 & FCA, FIA in boosters & 4 & $\begin{array}{l}\text { Mean litter size } \\
8.9,3.2\end{array}$ & $P<0.0001$ & 64 & $\begin{array}{l}\text { Naz \& Zhu } \\
\text { (1998) }\end{array}$ \\
\hline $\begin{array}{l}\text { Second schedule } \\
\text { (283 days) }\end{array}$ & Murine rFA-1 & FCA, FIA in boosters & 4 & $\begin{array}{l}\text { Mean litter size } \\
8.6,9\end{array}$ & $P>0.05$ & 0 & $\begin{array}{l}\text { Naz \& Zhu } \\
\text { (1998) }\end{array}$ \\
\hline \multicolumn{8}{|l|}{ BALB/c mouse } \\
\hline First schedule & sp56FLAG & FCA, FIA in boosters & 6 & $\begin{array}{l}\text { Offspring/females } \\
55 / 14,12 / 5\end{array}$ & $P=0017$ & 39 & $\begin{array}{l}\text { Hardy \& } \\
\text { Mobbs (1999) }\end{array}$ \\
\hline
\end{tabular}


Table 2 Continued.

\begin{tabular}{|c|c|c|c|c|c|c|c|}
\hline Species & Immunogen & Adjuvant & $\begin{array}{c}\text { No. of } \\
\text { immunizations }\end{array}$ & $\begin{array}{l}\text { Reproductive } \\
\text { performance } \\
\text { (control, treated) }\end{array}$ & $\begin{array}{c}\text { Statistical } \\
\text { significance }^{\mathrm{a}}\end{array}$ & $\begin{array}{c}\text { Reduction } \\
\text { in relative } \\
\text { fertility }(\%)^{\mathrm{b}}\end{array}$ & Reference \\
\hline Second schedule & sp56FLAG & FCA, FIA in boosters & 4 & $\begin{array}{l}\text { Offspring/females } \\
55 / 14,19 / 5\end{array}$ & Not stated & 3 & $\begin{array}{l}\text { Hardy \& } \\
\text { Mobbs (1999) }\end{array}$ \\
\hline \multicolumn{8}{|l|}{ BALB/c mouse } \\
\hline First schedule & $\begin{array}{l}\text { MBP-polyepi- } \\
\text { tope A }\end{array}$ & FCA, FIA in boosters & 4 & $\begin{array}{l}\text { Mean litter size } \\
5.2,3.3\end{array}$ & Not stated & 37 & $\begin{array}{l}\text { Hardy et al. } \\
(2002 a)\end{array}$ \\
\hline Second schedule & $\begin{array}{l}\text { MBP-polyepi- } \\
\text { tope B }\end{array}$ & FCA, FIA in boosters & 4 & $\begin{array}{l}\text { Mean litter size } \\
5.2,2.1\end{array}$ & $P<0.05$ & 60 & $\begin{array}{l}\text { Hardy et al. } \\
(2002 a)\end{array}$ \\
\hline Third schedule & $\begin{array}{l}6 \text { XHis-polye- } \\
\text { pitope A }\end{array}$ & FCA, FIA in boosters & 4 & $\begin{array}{l}\text { Mean litter size } \\
6.5,6.3\end{array}$ & Not stated & 3 & $\begin{array}{l}\text { Hardy et al. } \\
(2002 a)\end{array}$ \\
\hline
\end{tabular}

Investigations have been conducted on approximately 70 species. This table includes only true experiments, i.e. studies with an immunized group compared with a control group.

${ }^{\text {aT }}$ The $P$ values are those given in the references cited. ${ }^{b}$ Relative fertility is defined as the mean no. of offspring for females in the vaccinated group divided by the same figure for the control group (i.e. unimmunized females).

Reproduction is a good example of a threshold character; it is an all-or-none attribute which can be affected by a variety of underlying genetic and environmental factors. If heritabilities are high, rapid selection occurs. This is shown by the high percentage of non-responders that occur within one generation (Table 3).

A limited place for immunocontraception in wildlife management could be in species with long generation times. Genetic changes in them, if they occur, will take decades. Claims have been made for the potential efficacy of immunocontraception for African elephants (Fayrer-Hosken et al. 2000, Delsink et al. 2002), although this view has been challenged on demographic grounds (Pimm \& van Aarde 2001). Long-term studies on immunocontraception in wild horses report $78-94.2 \%$ contraceptive efficacy (Kirkpatrick et al. 1995, Turner et al. 1997, 2002, Turner \& Kirkpatrick 2002).

Zoo animals are convenient for immunocontraception studies of wild species, because of their long-term accessibility, although the small numbers usually available make controls hard to find. This is illustrated by an investigation involving 27 females from 10 felid species. Immunization with PZP and Freund's Complete Adjuvant gave several kinds of adverse reaction but no convincing evidence of an effect upon fertility (Harrenstien et al. 2004).

Table 3 Predicted proportion of non-responder daughters after one generation of selection by immunocontraception of mothers given various heritabilities (after Falconer 1965).

\begin{tabular}{lcccr}
\hline & \multicolumn{4}{c}{ Heritability (\%) } \\
\cline { 2 - 5 } $\begin{array}{l}\text { Non-responder } \\
\text { mothers (\%) }\end{array}$ & 100 & 80 & 60 & 50 \\
\hline 5 & 15 & 11 & 10 & 8 \\
10 & 23 & 19 & 16 & 15 \\
\hline
\end{tabular}

The prediction has been arrived at by entering the table in Falconer (1965) which relates heritability for a threshold trait to incidences in parent and offspring. The response to selection (predicted percentage of non-responders) obtained has been halved because selection is being carried out on one sex.
Delves \& Roitt (2005) review attempts to immunocontracept mammals and conclude that $\mathrm{GnRH}$ is the most promising target, because of its evolutionary conserved sequence.

\section{Immunogenetic issues}

Infectious diseases are assumed to be one of the main classes of selective forces which act upon genes controlling immune responses (Klein et al. 1993). Immunocontraceptive agents also have the potential to influence the genetic constitution of a population with respect to the ability to mount immune responses. The two are similar in that pathogens which cause plagues and immunocontraceptive agents are both capable of exerting very strong selective pressure with the potential for rapid genetic change. However, they differ in two important respects. First, most pathogens are cellular and antigenically more complex than most immunocontraceptive agents, which consist of one or a few proteins and in some cases associated carbohydrate. Second, they have opposite directions of selection; resistance to a pathogen involves a positive response, whereas resistance to an immunocontraceptive involves non-response. The consequences of this kind of selection imposed by an immunocontraceptive agent require study. It seems likely that it will alter the immunogenetic constitution of the target species. The existence of genes governing response to pathogens is well documented in humans for malaria (Hill 2001), tuberculosis (Blackwell 1998, Bellamy 2003), and HIV (McNicholl \& Cuenco 1999, Carrington \& O'Brien 2003). Relevant examples are found in New Zealand Red Deer in which susceptibility to tuberculosis has high heritability (Mackintosh et al. 2000) and in the NRAMP1 association with the human response to leishmaniasis (Bucheton et al. 2003). The complexities of the co-evolution of pathogens and hosts and its biomedical significance are beginning to be unraveled (Woolhouse et al. 2002). Both experimental (Lively \& Dybdahl 2000) and theoretical analyses (e.g. Nowak 
\& May 1994) point to the inherent difficulties of prediction of the course of these interactions. Prediction and detection of the ecopathological consequences of the use of immunocontraception of wild animals will also be made difficult by the spread of emerging infectious diseases as a result of human activity (Daszak et al. 2000).

The effect of immunocontraception upon genetic diversity could be significant. There is the possibility that restriction of breeding to a small group of animals which are closely related will result in localized inbreeding. This will be especially likely if their capacity to resist the immunocontraceptive is the result of shared uncommon genotype. Acevedo-Whitehouse et al. (2003) have shown that in California sea lions, inbreeding is associated with a wide range of diseases. They suggest that inbred individuals could act disproportionally as reservoirs of infectious agents.

Selection based upon immune responses could be on one of two parts of the genome: the MHC (major histocompatability complex) region which governs responses to specific immunogens, or other genes, e.g. NRAMP which govern the functioning of the immune system in general (Bellamy 1999). The tightly linked $M H C$ genes and the resultant linkage disequilibrium mean that selection on one gene will result in changes in gene frequencies at other loci. This could either raise or lower susceptibility to other pathogens. Understanding of the non-MHC genetic component of variability of the immune response is much less advanced than for the MHC component. This understanding is needed to attempt any predictions concerning immunocontraception-based selection.

Experimental approaches to this question have until now been very difficult. The existence of genetic maps of some wild animals (e.g. Tammar wallaby (Zenger et al. 2002)) may now allow a genomic approach, in which whole genome DNA typing may allow the identification of changes in gene frequency which accompany the application of immunocontraception or a pathogen, through comparing treated and control populations. A concomitant survey of pathogens in the two groups may identify susceptibility regions, whose existence could be further tested in lab-based investigation. The genome would thus be assayed for these genes, and test the extent to which the same genes are involved in responses to different pathogens and to immunocontraception.

A good model system to address these questions is wildlife tuberculosis which is of economic significance in several countries, e.g. Britain (Delahay et al. 2002), New Zealand (Buddle et al. 2002), and the United States (Palmer et al. 2002). Considerable information on the genetic control of response to mycobacterial antigens is available (North \& Medina 1998, Kramnik et al. 2000, Bellamy 2003). The possibility of obtaining results relevant to human mycobacterial susceptibility may also encourage use of this system.

We conclude that attempting to use the immunological system to modulate reproduction could be incompatible with the basic biological function of resisting pathogens. We have not discussed some of the practical issues. For example, all fertility control methods have the problem of delivery of the control agent. Highly valued animals must be treated without harming them. When this is the case, fertility control methods with fewer concomitant problems, such as surgical sterilization or the use of steroids or gonadotropin-based hormones, would be competitive with immunocontraception (Cooper \& Herbert 2001).

\section{Acknowledgements}

We acknowledge helpful comments from John Aitken, Tony Basten, Kathy Belov, David Briscoe, Bryce Buddle, Margaret Carrington, Charles Daugherty, Dick Frankham, Cathy Herbert, John McKenzie, Bill Sherwin, Jim Shields, Roger Short, and Kyall Zenger. Our research on population control in koalas and kangaroos is supported by the Australian Research Council grant LPO560344. The authors declare that there is no conflict of interest that would prejudice the impartiality of this scientific work.

\section{References}

Acevedo-Whitehouse K, Gulland F, Denise G \& Amos W 2003 Inbreeding: disease susceptibility in California sea lions. Nature 42235.

Aitken RJ 2002 Immunocontraceptive vaccines for human use. Journal of Reproductive Immunology 57 273-287.

Aitken RJ, Paterson M \& Koothan PT 1993 Contraceptive vaccines. British Medical Bulletin 49 88-99.

Baird DT 2000 Overview of advances in contraception. British Medical Bulletin 56 704-716.

Barber MR \& Fayrer-Hosken RA 2000 Possible mechanisms of mammalian immunocontraception. Journal of Reproductive Immunology 46 103-124.

Barlow ND 2000 The ecological challenge of immunocontraception: editor's introduction. Journal of Applied Ecology 37 897-902.

Basten A 1988 Birth control vaccines. Baillière's Clinical Immunology and Allergy 2 759-774.

Becker Y 2000 Evolution of viruses by acquisition of cellular RNA or DNA nucleotide sequences and genes: an introduction. Virus Genes 21 7-12.

Bellamy R 1999 The natural resistance-associated macrophage protein and susceptibility to intracellular pathogens. Microbes and Infection $123-27$.

Bellamy R 2003 Susceptibility to mycobacterial infections: the importance of host genetics. Genes and Immunity 4 4-11.

Berger J 1986 Wild Horses of the Great Basin: Social Competition and Population Size, Chicago: University of Chicago Press.

Blackwell JM 1998 Genetics of host resistance and susceptibility to intramacrophage pathogens: a study of multicase families of tuberculosis, leprosy and leishmaniasis in north-eastern Brazil. International Journal for Parasitology 28 21-28.

Bomford M, Newsome A \& O'Brien P 1996 Solutions to feral animal problems: ecological and economic principles. In Conserving Biodiversity: Threats and Solutions, pp 202-209. Eds RA Bradstock, DA Keith, RT Kingsford, D Lunney \& DP Sivertsen. Sydney: Surrey Beatty and Sons.

Brown RG, Kimmins WC, Mezei M, Parsons JL, Phoajdak B \& Bowen WD 1996 Birth control for grey seals. Nature 379 30-31. 
Brown RG, Bowen WD, Eddington JD, Kimmins WC, Mezei M, Parsons JL \& Pohajdak B 1997 Evidence for a long-lasting single administration contraceptive vaccine in wild grey seals. Journal of Reproductive Immunology 35 43-51.

Bucheton B, Abel L, Kheir MM, Mirgani A, El-Safi SH, Chevillard C \& Dessein A 2003 Genetic control of visceral leishmaniasis in a Sudanese population: candidate gene testing indicates a linkage to the NRAMP1 region. Genes and Immunity 4 104-109.

Buddle BM, Skinner MA, Wedlock DN, Collins DM \& de Lisle GW 2002 New generation vaccines and delivery systems for control of bovine tuberculosis in cattle and wildlife. Veterinary Immunology and Immunopathology 87 177-185.

Butterworth DS, Duffy DC, Best PB \& Bergh MO 1988 On the scientific basis for reducing the South African seal population. South African Journal of Science 84 179-188.

Carrington M \& O'Brien SJ 2003 The influence of HLA genotype on AIDS. Annual Review of Medicine 54 535-551.

Caughley J, Bomford M, Parker B, Sinclair R, Griffiths J \& Kelly D 1998 Managing Vertebrate Pests: Rodents, Canberra: Bureau for Rural Sciences.

Chambers LK, Lawson MA \& Hinds LA 1999 Biological control of rodents - the case for fertility control using immunocontraception, Ecologically-Based Management of Rodent Pests, Canberra: Australian Centre for International Agricultural Research.

Choquenot D, Mcllroy J \& Korn T 1996 Managing Vertebrate Pests: Feral Pigs, Canberra: Bureau of Rural Sciences.

Cooper DW \& Herbert CA 2001 Genetics, biotechnology and population management of over-abundant mammalian wildlife in Australasia. Reproduction, Fertility, and Development 13 451-458.

Curtis PD, Pooler RL, Richmond ME, Miller LA, Mattfeld GF \& Quimby FW 2002 Comparative effects of GnRH and porcine zona pellucida (PZP) immunocontraceptive vaccines for controlling reproduction in white-tailed deer (Odocoileus virginianus). Reproduction (Cambridge, England) Supplement 60 131-141.

Daszak P, Cunningham AA \& Hyatt AC 2000 Emerging infectious diseases of wildlife-threats to biodiversity and human health. Science 287 443-449.

Dawson TJ 1995 Kangaroo: Biology of the Largest Marsupial, Sydney: University of New South Wales Press.

Delahay RJ, De Leeuw AN, Barlow AM, Clifton-Hadley RS \& Cheeseman CL 2002 The status of Mycobacterium bovis infection in UK wild mammals: a review. Veterinary Journal 164 90-105.

Delsink AK, van Altena JJ, Kirkpatrick J, Grobler D \& Fayrer-Hosken RA 2002 Field applications of immunocontraception in African elephants (Loxodonta africana). Journal of Reproduction and Fertility. Supplement 60 117-124.

Delves PJ \& Roitt IM 2005 Vaccines for the control of reproductionstatus in mammals and aspects of comparative interest. Developments in Biologicals 121 265-273.

Delves PJ, Lund T \& Roitt IM 2002 Antifertility vaccines. Trends in Immunology 23 213-219.

Dobbie WR, Berman DMK \& Braysher ML 1993 Managing Vertebrate Pests: Feral Horses, Canberra: Bureau of Resource Sciences.

Donnelly CA, Woodroffe R, Cox DR, Bourne J, Gettinby G, Le Fevre AM, McInerney JP \& Morrison WI 2003 Impact of localized badger culling on tuberculosis incidence in British cattle. Nature 426 834-837.

Duckworth JA, Buddle BM \& Scobie S 1998 Fertility of brushtail possums (Trichosurus vulpecula) immunised against sperm. Journal of Reproductive Immunology 37 125-138.

Falconer DS 1965 The inheritance of liability to certain diseases, estimated from the incidence among relatives. Annals of Human Genetics 29 51-76.

Fayrer-Hosken RA, Grobler D, Van Altena JJ, Bertschinger HJ \& Kirkpatrick JF 2000 Immunocontraception of African elephants. Nature 407149.

Finkel E 2001 Australia. Engineered mouse virus spurs bioweapon fears. Science 291585.
Fleming PL, Corbett L, Harden R \& Thomson P 2001 Managing the Impacts of Dingoes and Other Wild Dogs, Canberra: Bureau of Rural Sciences.

Fraker MA, Brown RG, Gaunt GE, Kerr JA \& Pohajdak B 2002 Longlasting, single-dose immunocontraception of feral fallow deer in British Columbia. Journal of Wildlife Management 66 1141-1147.

Freeland WJ \& Choquenot D 1990 Determinants of herbivore carrying capacity: plants, nutrients and Equus asinus in Northern Australia. Ecology 71 589-597.

Furbish CE \& Albano M 1994 Selective herbivory and plant community structure in a mid-Atlantic salt marsh. Ecology 75 1015-1022.

Gorman SF, Levy JK, Hampton AL, Collante WR, Harris AL \& Brown RG 2002 Evaluation of a porcine zona pellucida vaccine for the immunocontraception of domestic kittens (Felis catus). Theriogenology 58 135-149.

Grandy JW \& Rutberg AT 2002 An animal welfare view of wildlife contraception. Reproduction (Cambridge, England) Supplement 60 $1-7$.

Gupta SK \& Talwar GP 1994 Contraceptive vaccines. Advances in Contraceptive Delivery Systems 10 255-265.

Hanks J 2001 Conservation strategies for Africa's large mammals. Reproduction, Fertility, and Development 13 459-468.

Hardy CM \& Mobbs KJ 1999 Expression of recombinant mouse sperm protein sp56 and assessment of its potential for use as an antigen in an immunocontraceptive vaccine. Molecular Reproduction and Development 52 216-224.

Hardy CM, Pekin J \& ten Have JF 2002a Mouse-specific immunocontraceptive polyepitope vaccines. Reproduction (Cambridge, England) Supplement 60 19-30.

Hardy CM, ten Have JF, Mobbs KJ \& Hinds LA 2002 b Assessment of the immunocontraceptive effect of a zona pellucida 3 peptide antigen in wild mice. Reproduction, Fertility, and Development 14 151-155.

Harrenstien LA, Munson L, Chassy LM, Liu IK \& Kirkpatrick JF 2004 Effects of porcine zona pellucida immunocontraceptives in zoo felids. Journal of Zoo and Wildlife Medicine 35 271-279.

Hill AV 2001 The genomics and genetics of human infectious disease susceptibility. Annual Review of Genomics and Human Genetics 2 373-400.

Ivanova M, Petrov M, Klissourska D \& Mollova M 1995 Contraceptive potential of procine zona pellucida in cats. Theriogenology 43 969-981.

Jackson RJ, Ramsay AJ, Christensen CD, Beaton S, Hall DF \& Ramshaw IA 2001 Expression of mouse interleukin-4 by a recombinant ectromelia virus suppresses cytolytic lymphocyte responses and overcomes genetic resistance to mousepox. Journal of Virology 75 1205-1210.

Joshi SH 1973 An immunological approach to fertility control. American Journal of Pharmacy 145 22-26.

Kerr PJ, Jackson RJ, Robinson AJ, Swan J, Silvers L, French N, Clarke H, Hall DF \& Holland MK 1999 Infertility in female rabbits (Oryctolagus cuniculus) alloimmunized with the rabbit zona pellucida protein ZPB either as a purified recombinant protein or expressed by recombinant myxoma virus. Biology of Reproduction 61 606-613.

Kirkpatrick JF, Liu IKM, Turner JW \& Bernoco M 1991 Antigen recognition in feral mares previously immunized with porcine zonae pellucidae. Journal of Reproduction and Fertility. Supplement 44 321-325.

Kirkpatrick JF, Naugle R, Liu IKM \& Turner JW 1995 Effects of Seven Consecutive Years of Porcine Zonae Pellucidae Contraception on Ovarian Function in Feral Mares, Biology of Reproduction Monograph Series. vol 1, pp 411-413 (Equine Reproduction VI).

Kitchener AL, Edds LM, Molinia FC \& Kay DJ 2002 Porcine zonae pellucidae immunization of tammar wallabies (Macropus eugenii): fertility and immune responses. Reproduction, Fertility, and Development 14 215-223.

Klein J, Satta Y, O'HUigin C \& Takahata N 1993 The molecular descent of the major histocompatibility complex. Annual Review of Immunology 11 269-295.

Kramnik I, Dietrich WF, Demant P \& Bloom BR 2000 Genetic control of resistance to experimental infection with virulent Mycobacterium tuberculosis. PNAS 97 8560-8565. 
Krebs JR, Anderson RM, Clutton-Brock T, Donnelly CA, Frost S, Morrison WI, Woodroffe R \& Young D 1998 Badgers and bovine TB: conflicts between conservation and health. Science 279 817-818.

Lawson M 1995 Rabbit virus threatens ecology after leaping the fence. Nature 378531.

Leenaars PP, Hendriksen CF, Angulo AF, Koedam MA \& Claassen E 1994 Evaluation of several adjuvants as alternatives to the use of Freund's adjuvant in rabbits. Veterinary Immunology and Immunopathology 40 225-241.

Leenaars PP, Koedam MA, Wester PW, Baumans V, Claassen E \& Hendriksen CF 1998 Assessment of side effects induced by injection of different adjuvant/antigen combinations in rabbits and mice. Laboratory Animals 32 387-406.

Lively CM \& Dybdahl MF 2000 Parasite adaptation to locally common host genotypes. Nature 405 679-681.

Mackintosh CG, Qureshi T, Waldrup K, Labes RE, Dodds KG \& Griffin JF 2000 Genetic resistance to experimental infection with Mycobacterium bovis in red deer (Cervus elaphus). Infection and Immunity 68 1620-1625.

Mahlow JC \& Slater MR 1996 Current issues in the control of stray and feral cats. Journal of the American Veterinary Medical Association 209 2016-2020.

Martin R \& Handasyde K 1999 The Koala: Natural History, Conservation and Management, Sydney: University of New South Wales Press Ltd.

McCool CJ 1981 Feral Donkeys in the Northern Territory: Report to the Feral Animals Committee of a Working Party on the Feral Donkey Problem, Darwin: Department of Primary Production.

McKenzie JA 1996 Ecological and Evolutionary Aspects of Insecticide Resistance, Texas, USA: Academic Press/R.G. Landes.

McNicholl JM \& Cuenco KT 1999 Host genes and infectious diseases. HIV, other pathogens, and a public health perspective. American Journal of Preventive Medicine 16 141-154.

McShea WJ, Underwood HB \& Rappole JH 1997 The Science of Overabundance: Deer Ecology and Population Management, Washington, D.C.: Smithsonian Institution Press.

Miller LA, Johns BE, Elias DJ \& Crane KA 1997 Comparative efficacy of two immunocontraceptive vaccines. Vaccine 15 1858-1862.

Miller LA, Johns BE \& Killian GJ 2000a Immunocontraception of whitetailed deer using native and recombinant zona pellucida vaccines. Animal Reproduction Science 63 187-195.

Miller LA, Johns BE \& Killian GJ $2000 \mathrm{~b}$ Immunocontraception of whitetailed deer with $\mathrm{GnRH}$ vaccine. American Journal of Reproductive Immunology 44 266-274.

Miller LA, Johns BE \& Killian GJ 2000c Long-term effects of PZP immunization on reproduction in white-tailed deer. Vaccine $\mathbf{1 8}$ $568-574$

Mohn R \& Bowen WD 1996 Grey seal predation on the Eastern Scotian Shelf: modeling the impact on Atlantic cod. Canadian Journal of Fisheries and Aquatic Sciences 53 2722-2738.

Montague TLe 2000 The Brushtail Possum: Biology, Impact and Management of an Introduced Marsupial, Lincoln, NZ: Manaaki Whenua Press.

Moore HD, Jenkins NM \& Wong C 1997 Immunocontraception in rodents: a review of the development of a sperm-based immunocontraceptive vaccine for the grey squirrel (Sciurus carolinensis). Reproduction, Fertility, and Development 9 125-129.

Naz RK \& Zhu X 1998 Recombinant fertilization antigen-1 causes a contraceptive effect in actively immunized mice. Biology of Reproduction 59 1095-1100.

Newsome AE 1991 Feral cats: an overview. In The Impact of Cats on Native Wildlife, Ed. C Potter. Canberra: Australian National Parks and Wildlife Service.

North RJ \& Medina E 1998 How important is Nramp1 in tuberculosis?. Trends in Microbiology 6 441-443.

Nowak MA \& May RM 1994 Superinfection and the evolution of parasite virulence. Proceedings of the Royal Society of London. Series B 255 81-89.
O'Hern PA, Liang ZG, Bambra CS \& Goldberg E 1997 Colinear synthesis of an antigen-specific B-cell epitope with a 'promiscuous' tetanus toxin T-cell epitope: a synthetic peptide immunocontraceptive. Vaccine 15 1761-1766.

Oogjes G 1997 Ethical aspects and dilemmas of fertility control of unwanted wildlife: an animal welfarist's perspective. Reproduction, Fertility, and Development 9 163-167.

Palmer MV, Waters WR \& Whipple DL 2002 Milk containing Mycobacterium bovis as a source of infection for white-tailed deer fawns (Odocoileus virginianus). Tuberculosis (Edinburgh, Scotland) 82 161-165.

Pimm SL \& van Aarde RJ 2001 Population control: African elephants and contraception. Nature 411766.

Pople T \& Grigg G 1999 Commercial Harvesting of Kangaroos in Australia, Canberra: Environment Australia.

Rao AJ 2001 Is there a role for contraceptive vaccines in fertility control?. Journal of Biosciences 26 425-427.

Richter J 1994 Anti-fertility 'vaccines': a plea for an open debate on the prospects of research. Newsletter (Women's Global Network on Reproductive Rights) 46 3-5.

Sabeta CT, Bingham J \& Nel LH 2003 Molecular epidemiology of canid rabies in Zimbabwe and South Africa. Virus Research 91 203-211.

Saunders GR, Coman B, Kinnear J \& Braysher M 1995 Managing Vertebrate Pests: Foxes, Canberra: Bureau of Rural Science.

Seamark RF 2001 Biotech prospects for the control of introduced mammals in Australia. Reproduction, Fertility, and Development 13 705-711.

Shideler SE, Stoops MA, Gee NA, Howell JA \& Lasley BL 2002 Use of porcine zona pellucida (PZP) vaccine as a contraceptive agent in free-ranging tule elk (Cervus elaphus nannodes). Reproduction (Cambridge, England) Supplement 60 169-176.

Stevens VC 1975 Potential control of fertility in women by immunization with HCG. Research in Reproduction 1-2.

Turner A \& Kirkpatrick JF 2002 Effects of immunocontraception on population, longevity and body condition in wild mares (Equus caballus). Reproduction (Cambridge, England) Supplement 60 187-195.

Turner JW, Liu IKM \& Kirkpatrick JF 1996 Remotely delivered immunocontraception in free-roaming feral burros (Equus asinus). Journal of Reproduction and Fertility 107 31-35.

Turner JW, Liu IKM, Rutberg AT \& Kirkpatrick JF 1997 Immunocontraception limits foal production in free-roaming feral horses in Nevada. Journal of Wildlife Management 107 31-35.

Turner JW, Liu IKM, Flanagan DR, Bynum KS \& Rutberg AT 2002 Porcine zona pellucida (PZP) immunocontraception of wild horses (Equus caballus) in Nevada: a 10 year study. Reproduction (Cambridge, England) Supplement 60 177-186.

Tyndale-Biscoe CH 1991 Fertility control in wildlife. Reproduction, Fertility, and Development 3 339-343.

Tyndale-Biscoe CH 1994 Virus-vectored immunocontraception of feral mammals. Reproduction, Fertility, and Development 6 281-287.

Warren RJ 1997 The challenge of deer overabundance in the 21st century. Wildlife Society Bulletin 25 213-214.

Williams K, Parer I, Coman B, Burley J \& Braysher M 1995 Managing Vertebrate Pests: Rabbits, Canberra: Bureau of Rural Science.

Woolhouse ME, Webster JP, Domingo E, Charlesworth B \& Levin BR 2002 Biological and biomedical implications of the co-evolution of pathogens and their hosts. Nature Genetics 32 569-577.

Zenger KR, McKenzie LM \& Cooper DW 2002 The first comprehensive genetic linkage map of a marsupial: the tammar wallaby (Macropus eugenii). Genetics 162 321-330.

Received 21 May 2006

First decision 22 June 2006

Revised manuscript received 30 July 2006

Accepted 10 October 2006 